\title{
Engaging with Text: The Effectiveness of Content Literacy and Active Learning Strategies in Online Introductory Accounting Courses
}

\author{
Rachel Raskin
}

\section{ABSTRACT}

Language and literacy are innate to learning. The accounting language is technical and specific, and students must become literate in the discipline to be able to critically read and understand accounting text and apply their knowledge. Introductory accounting courses are typically difficult for students, who struggle to simply pass the course. Students memorize the concepts but cannot internalize the information. Lack of active reading and literacy skills hinders higher order thinking needed to solve problems.

The study discussed in this paper involves two fully online introductory accounting courses where one of the courses is taught leveraging literacy strategies (experimental course) and the other without literacy instruction (control course). Initial and final reading assessments are implemented in both courses and the results demonstrate an overall greater improvement in students' comprehension, analysis, context and evaluation skills in the experimental class.

Published Online: July 25, 2021

ISSN: $2736-4534$

DOI : $10.24018 /$ ejedu.2021.2.3.100

\section{Rachel Raskin}

City University of New York - New York City College of Technology in Brooklyn, NY, USA.

(e-mail: rraskin@ citytech.cuny.edu)

Keywords: accounting, content literacy, literacy strategies, engagement, online instruction.

\section{INTRODUCTION}

Motivating students to read is a challenge faced by instructors throughout disciplines. Often when students do read, they merely memorize facts instead of engaging with the text and consequently do not internalize the information. Content reading is typically higher-level reading full of complex vocabulary and usually relies on prior knowledge to gain understanding. Students struggle to meet content reading requirements often because they are not prepared for collegelevel reading and may not find content reading interesting. In the digital world where anything can easily be looked up on the internet, students often fail to see the importance of reading for learning.

"A majority of U.S. adolescents can comprehend factual information, but few could extend or elaborate the meanings of the materials they read. Further, "Adolescents entering the adult world in the 21st century will read and write more than at any other time in human history, needing advanced levels of literacy to perform their jobs and to cope with the flood of information they will find everywhere they turn. Continual instruction beyond the early grades is needed" [23]. Students must leverage techniques such as strategic reading to help them read and understand a wide range of non-fiction and technical texts [7]. Strategies are needed to construct meaning from text and "reading instruction should enable students to become skillful readers who routinely apply procedures that contribute to interpretation" [17]. High-school students are not prepared for the demands of college because they do not know how to study as they never had to truly learn to get good grades and thus come to college with unrealistic expectations
[21]. "Teachers need to be proficient in their subject matter as well as understand how to help their students develop the sophisticated skills needed to read texts in ways that are specific to their content area(s)" [14].

Content literacy is the ability to use reading and writing for the acquisition of new content in a discipline. Reading and writing together facilitate higher order thinking such as synthesis and evaluation to clarify, refine and extend one's internalization of content [22]. Teaching course content jointly with active reading and writing strategies can enhance learning. The key to learning is metacognitive processing, which is supported by procedural and focused strategies that arise while reading [29]. The National Survey of America's College Students (NSACS) examined the literacy of U.S. college students in 2006, examining three prongs of literacy prose literacy, document literacy, and quantitative literacy, to inform the relationship among educational experience, literacy, and preparedness for the job market. The results of the study show higher levels of literacy among students enrolled in classes emphasizing analytic thinking, such as evaluating the strength of arguments and applying theories to practical problems or new situations [3].

Accounting is considered 'the language of business' because it tells the story of what is happening in a business. Accounting communicates financial information to people both internal and external to the company, providing analysis and business intelligence. Cultivating students' ability to perform such high-level functions can practically be attained by close reading of a variety of accounting related texts, together with the use of a range of cognitive and metacognitive learning skills [6]. Yet, accounting instructors 
typically focus on technical mastery and rule memorization over teaching literacy and the metacognitive processes needed to become proficient in the rich accounting language. Perhaps consequently, introductory accounting courses characteristically have low pass rates and high attrition rates [19]. Technical knowledge acquired by memorizing information is not internalized and therefore students struggle to apply knowledge in order to solve accounting problems.

The shift to virtual instruction, intensified and necessitated by the COVID-19 pandemic, has made it increasingly difficult to monitor student literacy. Getting students to read in a traditional in-person class is not easy but encouraging students to engage with the text in an online course is an arduous but necessary task. Online learning requires highlevel skills, such as self-motivation, that some students may have not yet developed. The instructor must therefore spark and maintain student motivation [8].

\section{METHOD}

The study examines the impact of incorporating active reading, writing, and learning strategies on content literacy in a fully online introductory accounting course at a public urban, minority serving college in New York. The participants were students in their freshmen or sophomore year of college, studying accounting, computer systems technology, marketing, management \& sales, or the business of fashion. Research-based active reading strategies were implemented in one course section while a second section of the same course was taught without leveraging reading strategies. As part of the College's Reading Across the Curriculum (READ) program, initial and final assessments were administered at the beginning and at the end of the semester. READ is a multi-component program in which reading and content area faculty work together to design discipline-specific reading strategies to improve student learning by reading for learning.

A content reading was administered to two introductory accounting classes along with eight questions that assessed the following performance criteria on a rubric scale of one to four to obtain a baseline score: comprehension, analysis, context and evaluation. Students were asked to read a news article discussing how accounting inconsistencies in a wellknown company were impacting business operations. The students were notified that the assignment would be graded in order to enhance motivation. At the end of the semester both classes were given another reading along with a set of questions assessing the same performance criteria. The two chosen readings are similar in length and students had sufficient prior knowledge to be able to understand both readings. Prior knowledge of content, along with general and content specific literacy skills are the main cognitive components of content literacy; existing content knowledge facilitates reading and writing activities to acquire more knowledge [22].

Active reading and learning strategies were implemented throughout the semester in the experimental class $(n=32)$. The other course section $(n=29)$, representing the control group, was taught without literacy instruction and active reading strategies. The results of the two assessments are discussed to ascertain whether the literacy strategies used throughout the semester improved student performance on the measured criteria.

\section{EVIDENCE - BASED STRATEGIES}

The literacy and metacognitive learning strategies that were implemented in the experimental introductory accounting course section are discussed.

\section{A. Effective Note Taking}

Metacognitive readers can monitor their understanding of the text while reading [13]. Learners retain material better when they generate it themselves and begin to learn and memorize during note taking. Note taking is a combination of storing and encoding information. Taking notes and reviewing them is thus a vital component of successful learning [4]. There is a three-step process for getting new learning into your long-term memory. This first step is to encode the information to keep it in short-term memory and this can be accomplished by taking notes. Then, the information must be consolidated to make connections between the new information and pre-existing knowledge stored in long-term memory. Consolidating the information can be achieved by rewriting the notes taken in the encoding stage. Finally, reviewing the notes helps in the retrieval step where the acquired information can be applied as needed. Notes can also be used as self-quizzes [5]. Taking notes by hand improves the ability to apply knowledge [25]. Students writing by hand must process and condense the material Taking notes serves a dual purpose - to physically store and cognitively encode content. Typing notes improves storage of material but weakens encoding [10], thus barring higher-level cognition.

To guide and encourage students to engage in effective note taking, an outline of each lecture was made available for students to follow while reading or listening to the content with space allotted to take notes. The outline highlights the important content that students should focus on when elaborating on their notes and reflects the learning outcomes of the lecture. The outline also includes a hierarchy of focus questions reflecting increasing levels of cognition to steer and deepen students' understanding of the material. It guides students through the process of content acquisition, starting with understanding and grasping the content to analyzing and applying the content. Below is an example of focus questions relating to a reading about the accounting cycle.

TABLE I: FOCUS QUESTIONS STRUCTURED USING INCREASING COGNITIVE LEVELS TO ENCOURAGE EFFECTIVE NOTE TAKING.

\begin{tabular}{cl}
\hline Cognitive Level & \multicolumn{1}{c}{ Focus Question } \\
\hline Understand & What are adjusting entries? \\
& Why is there a need for adjusting entries? \\
Apply & What is the difference between deferrals and \\
& accruals? \\
& Which accounting principle creates the need for \\
Analyze & adjusting entries? \\
& If deferral adjusting entries were not made, \\
& which financial statements would be impacted \\
& and how? \\
& If accrual adjusting entries were not made, \\
Evaluate & which financial statements would be impacted \\
& and how? \\
& As of $12 / 31$, ABC Co. owes $\$ 1000$ to \\
employees for hours worked between $12 / 27$ and & $12 / 31$. What adjusting entry must be recorded? \\
\hline
\end{tabular}


Students were instructed to freely write notes and then refine them after the lecture / reading by rewriting the concepts, making connections and logging questions that require further clarity. The notes were then sent to the instructor for review on a weekly basis and represented a minor portion of the final grade. The instructor reviewed student notes and returned them with comments and answers to the questions or concerns indicated. Students were then asked to revisit their notes and organize the content to create reference cards that were to be used on quizzes and exams. As information on reference cards is minimal, students were guided to consider the learning objectives that would be assessed and the key concepts from the notes that would help to better understand the objectives. Reference cards promote the use of notes to review and organize important concepts, enabling a more profound understanding of the content.

\section{B. Active Learning with Groups}

Group activities create a sense of community in a seemingly anonymous and desolate digital course. Students are encouraged to become active in their learning and accountable to their peers while capitalizing on diverse perspectives. Group activities facilitate discussion of the content, enabling students to make connections with prior knowledge and enriching the learning process. Creating a sense of belonging in the online learning environment motivates students; providing opportunities for interaction improves success in online learning [15].

Students need the ability to construct meaning by interacting with the content, fellow students, and the instructor [28]. Collaborative group activities combined with explicit instruction in reading strategy use can be structured to enhance content literacy. Collaborative learning prompts students to become more metacognitive and aware of their use of specific strategies, enhancing motivation as they become active participants in their learning [24]. Collaborative learning can be successful only if activities are structured and students are given clear expectations and instructions.

At the start of the semester, students were asked to complete a survey describing their background, learning styles, schedule and optimal availability for group work. This information was used to best match students into their

respective groups.

\section{Jigsaw}

The goal of jigsaw is to foster collaborative reading and discussion [1]. The class was divided into small groups of about five students and students within each group were then assigned a number 1-5. The original group was considered the "home group". The assigned number represents the "expert group" the student joined. Each expert group was assigned a different reading, or a specific part of a long reading. For example, each student in a home group assigned a number ' 2 ' went to expert group 2 to read, discuss, and summarize the text assigned to that group. Next, all students went back to their home groups and each student taught members of the group about the text they had just studied (members of the home groups all analyzed different parts of the readings). Groups were encouraged to make connections among all the readings in a video presentation and written summary that was submitted for grading.

In virtual classes, this can easily be accomplished by utilizing meeting rooms on platforms like Zoom along with discussion forums, Dropbox, and Google Docs. Group assignments must be posted well in advance along with the reading and well-written instructions.

For example, students were asked to perform a guided reading of different sections of a well- known public company's annual report and formulate responses to questions that address various aspects of the company's financial health. An example of the reading breakdown among groups would be the sections on Risk Factors, Legal Proceedings, Management Discussion \& Analysis, and selected Notes to the Financial Statements. Students collaborated with their peers to perform qualitative financial statement analysis, learning to better understand how various situations and events impact the financial statements while bolstering content literacy, writing and team-building skills. The 'expert' students returned to their respective home groups to bring the fragments of knowledge together and formulate a written discussion describing the health of the company. Students were reminded that a chain is only as strong as its weakest link to prompt them to engage with the text to heighten their comprehension and bolster the group deliverable. By teaching their peers, students remained engaged as they developed in-depth mastery of content.

\section{Concept Mapping}

Concept maps are graphic tools used to organize and represent knowledge in a hierarchical structure, using crosslinks to show relationships between concepts in different segments of the concept map [26]. Concept mapping is a powerful cooperative activity as it activates higher order thinking skills, demonstrating students' understanding of the main ideas of a text and how they are related. The volume of technical accounting concepts weaved in textbook chapters often confuse students who struggle to make meaningful connections between the topics. Concept maps are a way to develop logical thinking and study skills by revealing connections and helping students see how individual ideas form a larger whole [12]. Organizing knowledge helps students discern which information is important and enables them to make connections as they recognize relationships among concepts. Understanding the structural foundation of content improves comprehension as structural knowledge is essential to problem-solving [18]. The accounting domain is well-suited to the underlying learning theory of concept mapping as knowledge is organized into a hierarchical framework where learners build upon elementary knowledge and add more ideas and concepts to what they know [20].

Concept maps were modeled and discussed in the lectures. Guidance on how to create the concept maps was distributed, instructing students to list all the concepts and then start forming lines to show relationships among some of the concepts. They were asked to identify the main concept to use as the top of the concept hierarchy, which should then branch out into additional relevant concepts that could be dissected into more acute ideas. The relationships between the concepts should be demonstrated by words or phrases. 
Students formed groups to organize their lecture notes and form connections between the concepts and prior knowledge. Students registered for an account with Miro (Miro.com), an online collaborative whiteboarding platform where users can invite teammates to brainstorm and work on concept maps together. Concept mapping is fundamentally different than typical copious note taking as it entails categorizing a substantial amount of material into just a few concepts that must be connected using limited words. Repeated practice is needed for the concept maps to start to take shape and demonstrate a deep understanding of the content. The concept maps each group created were used as a low-stakes formative assessment, graded based on the number of connections made and the logic of the relationships.

The benefit of the Miro platform is that not only can the students brainstorm and work simultaneously to develop the concept maps, but the instructor can intervene to provide guidance and feedback while the students work together and once the maps are complete. Thus, the instructor can gain insight into students' understanding of the material and address gaps in knowledge as the students are in the process of forming connections between concepts, thereby aiding the learning process.

Students were periodically encouraged to revisit maps they made earlier in the semester and modify them with the added knowledge that they were able to better synthesize and apply. The maps initially showed few connections with vague labels and when reassessed at a later point, students were able to make more connections with more specific and accurate labels. Repeated practice of concept mapping with continuous feedback altered students' approach to reading the text. Students had mentioned that they began to doodle concept maps as they read each chapter and it helped to bring together the scattered pieces of information in the text into a cohesive understanding of the chapter content. This was evident in the concept map submissions as well as quiz grades that progressively improved as students started to gain the ability to apply integrated knowledge.

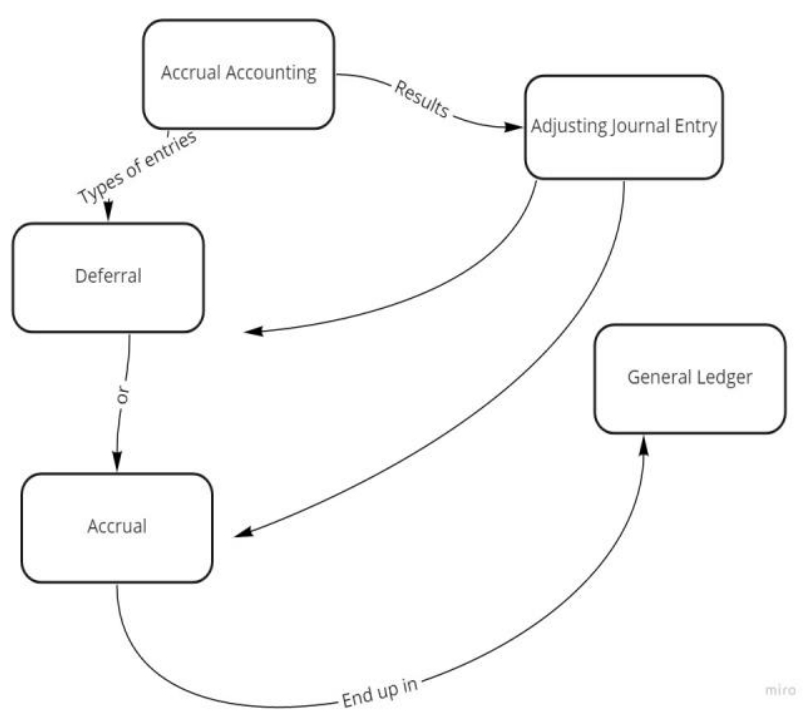

Fig. 1. A group concept map created using Miro in the beginning of the semester portraying the relationship between accrual accounting and adjusting entries.

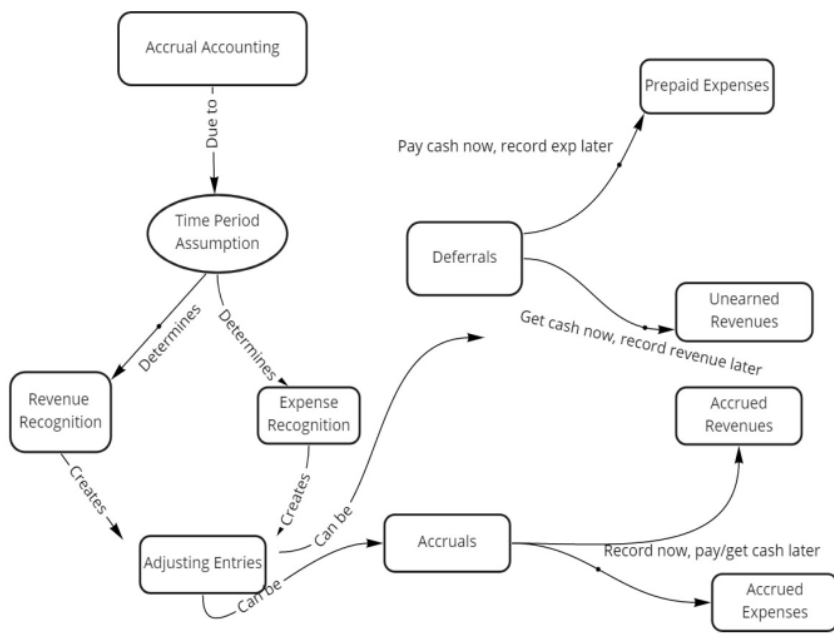

Fig. 2. A concept map revisited by the same group of students toward the middle of the semester. The students can now understand the underlying accounting principles that explain why adjusting entries are made and can accurately categorize and explain the various types of adjusting entries.

\section{E. Guided Discussion}

Weekly communication on the discussion forum was guided by questions related to a reading or case study, structured using the Question-Answer Relationship (QAR) cognitive strategy [27]. The readings contextualize the topics discussed in the textbook to bridge the gap between theory and practice. For instance, students engaged in a discussion around a reading and video describing a large-scale inventory fraud, exploring its impacts on the financial statements and stakeholders of the company involved.

Using the QAR strategy, students learned to categorize comprehension questions according to where they were likely to find the answers to the questions [11].

1) Text explicit questions are asked by quoting the text and the answer can be found directly in the text.

2) Text implicit questions can be answered by combining information from various places in the text.

3) Script and text implicit questions use the text as a background for answering the question, but the student must also draw upon existing knowledge of the topic.

4) Script implicit questions involve drawing upon prior knowledge and the text does not necessarily provide clues to the answer.

Referencing the instructor's model QAR activity, students were instructed to review the posted questions and categorize each question as text-explicit, text-implicit, script and textimplicit or script-implicit, briefly describing why they chose the given subcategory for each question. Students reflected on the questions and recognized where they should seek the proper information to answer them, whether that information is in the text, stored in their memory or required them to seek information they have not yet attained. The activity should be structured as scaffolded questioning where comprehension questions are asked before critical thinking questions so that foundational knowledge is utilized to prompt higher order thinking.

The QAR strategy can be used to improve comprehension and exam results across content areas, integrating content and literacy instruction [2]. Since problem solving requires textbased and brain-based thought processes, learning to utilize the QAR question types enables students to integrate both types of thinking to solve problems [9]. As such, QAR 
exercises are advantageous when studying accounting where problem solving entails the application of foundational knowledge together with more complex skills. QAR is conducive to discussion boards as script-implicit questions are typically open-ended and can therefore contribute to lively discourse among students.

After students posted their responses, the instructor asked them follow-up questions seeking explanation, challenging assumptions, and calling for evidence to cultivate thinking.

\section{RESUlts}

Both the initial and final assessments were comprised of eight questions, two questions designed to assess each of the performance criteria on a rubric scale of one to four comprehension, context, analysis, and evaluation. Student responses were assessed using the rubric adapted by the College's READ faculty, created by Professor Juanita But.

TABLE II: READ ASSESSMENT RUBRIC DEVELOPED BY JUANITA C. BUT (2015-2017)

\begin{tabular}{|c|c|c|c|c|}
\hline $\begin{array}{l}\text { Performance } \\
\text { Criteria }\end{array}$ & $\begin{array}{l}\text { Full Proficiency } \\
4 \\
\end{array}$ & $\begin{array}{c}\text { Adequate Proficiency } \\
3 \\
\end{array}$ & $\begin{array}{l}\text { Approaching Proficiency } \\
2 \\
\end{array}$ & $\begin{array}{c}\text { Low Proficiency } \\
1 \\
\end{array}$ \\
\hline Comprehension & $\begin{array}{l}\text { Understands the main idea and } \\
\text { major details in the text and is } \\
\text { able to make logical inferences. }\end{array}$ & $\begin{array}{l}\text { Understands most of the } \\
\text { information in the text and } \\
\text { is able to make some } \\
\text { logical inferences. }\end{array}$ & $\begin{array}{l}\text { Understands some ideas in the } \\
\text { text and struggles to make logical } \\
\text { inferences. }\end{array}$ & $\begin{array}{l}\text { Unable to understand the } \\
\text { main points of the text } \\
\text { and make logical } \\
\text { inferences. }\end{array}$ \\
\hline Analysis & $\begin{array}{l}\text { Able to identify text structure, } \\
\text { fully understand and analyze the } \\
\text { relationships among ideas, and } \\
\text { interpret information presented } \\
\text { in diverse formats and media. }\end{array}$ & $\begin{array}{l}\text { Able to identify text } \\
\text { structure, understand and } \\
\text { analyze some of the } \\
\text { relationships among ideas, } \\
\text { and interpret some } \\
\text { information presented in } \\
\text { diverse formats and media. }\end{array}$ & $\begin{array}{l}\text { Has some difficulties in } \\
\text { identifying text structure, } \\
\text { understand and analyze the } \\
\text { relationships among ideas, and } \\
\text { interpret information presented in } \\
\text { diverse formats and media. }\end{array}$ & $\begin{array}{l}\text { Unable to identify text } \\
\text { structure, understand and } \\
\text { analyze the relationships } \\
\text { among ideas, and } \\
\text { interpret information } \\
\text { presented in diverse } \\
\text { formats and media. }\end{array}$ \\
\hline Context & $\begin{array}{l}\text { Able to use concepts and ideas } \\
\text { in the text to solve problems } \\
\text { proficiently or make } \\
\text { connection/apply them to a new } \\
\text { context accurately and in a } \\
\text { meaningful and relevant way. }\end{array}$ & $\begin{array}{l}\text { Able to use concepts and } \\
\text { ideas in the text to solve } \\
\text { problems or make } \\
\text { connection/ apply them to } \\
\text { a new context accurately } \\
\text { but has some limitations. }\end{array}$ & $\begin{array}{l}\text { Able to use some concepts and } \\
\text { ideas in the text to solve problems } \\
\text { partially or make connection/ } \\
\text { apply them in a new context with } \\
\text { minor mismatching of } \\
\text { information and limitations. }\end{array}$ & $\begin{array}{l}\text { Unable to use concepts } \\
\text { and ideas in the text to } \\
\text { solve problems or make } \\
\text { connection/apply them in } \\
\text { a new context. }\end{array}$ \\
\hline Evaluation & $\begin{array}{l}\text { Identifies purpose and evaluates } \\
\text { the argument and specific } \\
\text { claims in a text with adequate } \\
\text { support, including valid } \\
\text { reasoning, relevant and } \\
\text { sufficient evidence. }\end{array}$ & $\begin{array}{l}\text { Identifies purpose and } \\
\text { evaluates the argument and } \\
\text { specific claims in a text } \\
\text { with some support, } \\
\text { including valid reasoning, } \\
\text { relevant and sufficient } \\
\text { evidence. }\end{array}$ & $\begin{array}{l}\text { Identifies purpose and evaluates } \\
\text { the argument and specific claims } \\
\text { in a text but with limited or no } \\
\text { support, including the valid } \\
\text { reasoning, relevant sufficient } \\
\text { evidence. }\end{array}$ & $\begin{array}{l}\text { Unable to identify } \\
\text { purpose and evaluate the } \\
\text { argument and specific } \\
\text { claims in a text, } \\
\text { including valid } \\
\text { reasoning, relevant and } \\
\text { sufficient evidence. }\end{array}$ \\
\hline
\end{tabular}

Tables III and IV show the results of the initial and final assessments in the experimental and control classes. Students who did not provide a response to a question received a score of ' 0 ' for that question.

TABLE III A: EXPERIMENTAL CLASS INITIAL ASSESSMENT (N=32)

\begin{tabular}{cccccc}
\hline & 4 & 3 & 2 & 1 & 0 \\
\hline COMPREHENSION & 15 & 31 & 8 & 7 & 3 \\
CONTEXT & 2 & 15 & 31 & 12 & 4 \\
ANALYSIS & 2 & 13 & 31 & 14 & 4 \\
EVALUATION & 5 & 35 & 19 & 3 & 2 \\
\hline
\end{tabular}

TABLE III B: EXPERIMENTAL CLASS FINAL ASSESSMENT (N=32)

\begin{tabular}{cccccc}
\hline & 4 & 3 & 2 & 1 & 0 \\
\hline COMPREHENSION & 33 & 26 & 5 & 0 & 0 \\
ANALYSIS & 15 & 32 & 16 & 1 & 0 \\
EVALUATION & 13 & 34 & 17 & 0 & 0 \\
CONTEXT & 14 & 37 & 12 & 1 & 0 \\
\hline
\end{tabular}

TABLE III C: EXPERIMENTAL CLASS MEAN RUBRIC SCORE IMPROVEMENT

\begin{tabular}{cccc}
\hline & $\begin{array}{c}\text { Initial } \\
\text { Assessment }\end{array}$ & $\begin{array}{c}\text { Final } \\
\text { Assessment }\end{array}$ & Change \\
\hline COMPREHENSION & 2.55 & 3.42 & $34 \%$ \\
CONTEXT & 1.95 & 2.92 & $50 \%$ \\
ANALYSIS & 1.78 & 2.95 & $66 \%$ \\
EVALUATION & 2.45 & 2.95 & $20 \%$ \\
\hline
\end{tabular}

TABLE IV A: CONTROL Class INITIAL ASSESSMENT $(\mathrm{N}=29)$

\begin{tabular}{cccccc}
\hline & 4 & 3 & 2 & 1 & 0 \\
\hline COMPREHENSION & 15 & 26 & 14 & 3 & 0 \\
CONTEXT & 2 & 14 & 28 & 11 & 3 \\
ANALYSIS & 11 & 13 & 19 & 10 & 5 \\
EVALUATION & 17 & 20 & 13 & 5 & 3 \\
\hline
\end{tabular}

TABLE IV B: CONTROL CLASS FINAL ASSESSMENT ( $\mathrm{N}=29)$

\begin{tabular}{lrrrrr}
\multicolumn{6}{c}{ TABLE IV B: CONTROL CLASS FINAL ASSESSMENT (N=29) } \\
\hline \multicolumn{1}{c}{4} & 3 & 2 & 1 & 0 \\
\hline COMPREHENSION & 10 & 31 & 16 & 1 & 0 \\
CONTEXT & 3 & 15 & 28 & 8 & 4 \\
ANALYSIS & 7 & 23 & 24 & 3 & 1 \\
EVALUATION & 11 & 26 & 15 & 5 & 1 \\
\hline
\end{tabular}

TABLE IV C: CONTROL ClASS MEAN RUBRIC SCORE IMPROVEMENT

\begin{tabular}{cccc}
\hline & $\begin{array}{c}\text { Initial } \\
\text { Assessment }\end{array}$ & $\begin{array}{c}\text { Final } \\
\text { Assessment }\end{array}$ & Change \\
\hline COMPREHENSION & 2.81 & 2.81 & $0 \%$ \\
CONTEXT & 1.97 & 2.06 & $-4 \%$ \\
ANALYSIS & 2.25 & 2.44 & $-9 \%$ \\
EVALUATION & 2.61 & 2.58 & $1 \%$ \\
\hline
\end{tabular}

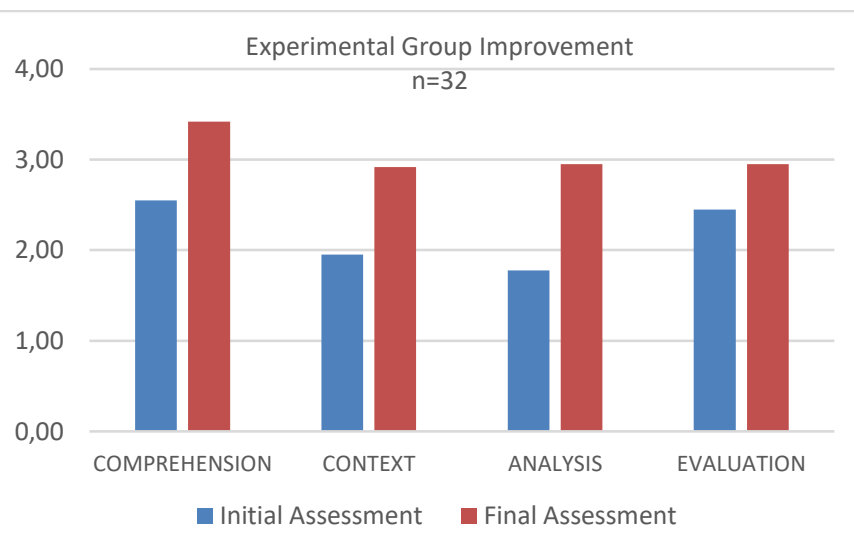

Fig. 3. Results of the initial and final assessments in the experimental class. Tables III A. and III B. show students' scores on the 8 questions in the initial assessment and the final assessment, categorized by competency. Table III C. shows the mean rubric scores for each competency and the change between the initial and final assessments. The results demonstrate 
improvement in all four of the performance criteria in the experimental class.

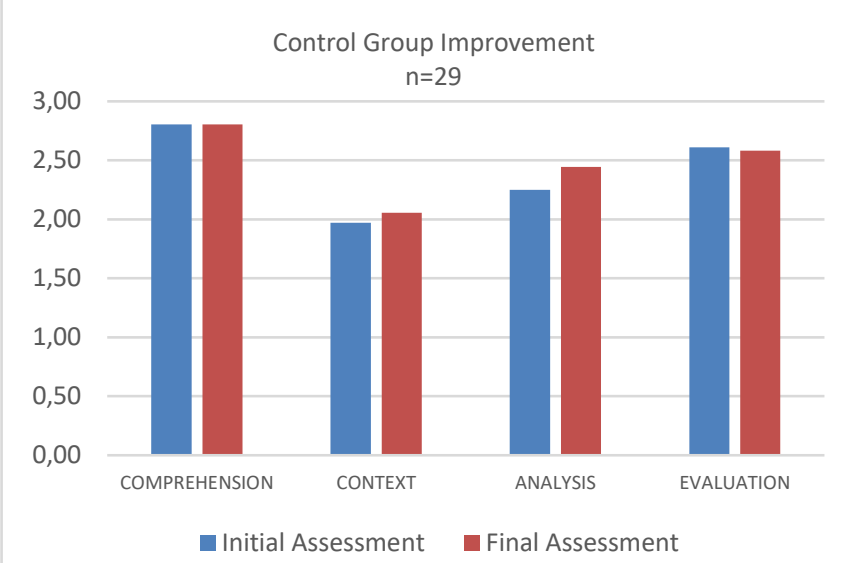

Fig. 4. Results of the initial and final assessments in the control course section. Tables IV A. and IV B. show students' scores on the initial assessment and the final assessments, categorized by competency. Table IV

C. shows the mean rubric scores for each competency and the change between the initial and final assessments. The results demonstrate little to no improvement in all four of the performance criteria in the control class.

The final grade distribution for both courses shows that $25 \%$ more students earned a grade of $\mathrm{C}$ or better in the experimental course $(91 \%)$ than in the control course $(66 \%)$.

TABLE V: FINAL GRADE DISTRIBUTION

\begin{tabular}{cccccc}
\hline \multicolumn{7}{c}{ Final Grade Distribution } \\
\hline & $\mathrm{A}$ & $\mathrm{B}$ & $\mathrm{C}$ & $\mathrm{D}$ & $\mathrm{F}$ \\
\hline Experimental Course & $28 \%$ & $28 \%$ & $34 \%$ & $3 \%$ & $6 \%$ \\
Control Course & $24 \%$ & $28 \%$ & $14 \%$ & $14 \%$ & $21 \%$ \\
\hline
\end{tabular}

\section{CONClusion}

The significantly greater increases in the mean rubric scores of the students in the experimental group as well as the increase in the percentage of students earning a grade of $\mathrm{C}$ or better reinforce the effectiveness of utilizing literacy and active learning strategies in introductory accounting courses.

In the experimental class, students' comprehension, context, and analysis skills show the greatest increases between the initial and final assessments. Students were better able to understand the main idea and the relationships among ideas in the text, internalize and apply concepts, and interpret the information in the text. Students' evaluation skills did not show as much improvement as the other competencies, calling for implementation of strategies focused more in-depth on cultivating students' abilities to evaluate arguments and details in a text. Further research is needed to identify and optimize such strategies.

Both the experimental and control groups had a mix of accounting, computer systems technology, marketing and management and fashion marketing students that were in their freshman or sophomore years of college. A limitation of the study is that the students' attributes in the two course sections were not closely analyzed for comparison purposes.

Supporting the literature, the study affirms that researchbased active reading strategies implemented as individual and group assignments enhance student engagement with the text and the course content and can be used to improve student motivation, which is typically lacking in the virtual learning environment. Integrating literacy skills in the content areas helps create stronger readers with a deeper understanding of content knowledge [16]. Accounting educators should strive to fill the gap in literacy instruction to enhance students' ability to internalize knowledge and apply it to solve problems and foster reading for learning.

\section{REFERENCES}

[1] E. Aronson, The Jigsaw Classroom, Beverly Hills, CA: Sage, 1978.

[2] K.H. Au, T. Raphael, "QAR: Enhancing comprehension and test taking across grades and content areas", The Reading Teacher, 59 (3) 206$221,2005$.

[3] J.D. Baer, A.L Cook, S. Baldi, "The Literacy of America's College Students", American Institutes for Research, 2006. Accessed The Literacy of America's College Students (ed.gov).

[4] A Boye, Note-taking in the 21st century: Tips for instructors and students [White paper], Texas Tech University, 2012. Retrieved https://www.depts.ttu.edu/tlpdc/Resources/Teaching_resour ces/TLPDC_teaching_resources/Documents/NotetakingWhitepaper.p df.

[5] P.C. Brown, H.L..Roediger, \& M.A. McDaniel, Make it stick: The science of successful learning. Belknap Press, 2014.

[6] M. Byrne., B. Flood, P.Willis, "An Inter-Institutional Exploration of the Learning Approaches of Students Studying Accounting". International Journal of Teaching and Learning in Higher Education, 20(2) 155-167, 2009.

[7] D.T. Conley, "Redefining College Readiness". Educational Policy Improvement Center, $2009 . \quad$ Retrieved from http://www.epiconline.org/collegeboard-advanced-placementbestpractices-course-study

[8] F. Darby, "How to be a Better Online Teacher". The Chronicle of Higher Education, 2019. Accessed How to Be a Better Online Teacher (chronicle.com)\.

[9] R.J. Draper \& M.E. McIntosh, "Using the Question-Answer Relationship Strategy to Improve Students' Reading of Mathematics Text", Clearing House, 69 (3) 154-163, 1996.

[10] S.Dynarski, "For note taking, low-tech is often best", Harvard Graduate School of Education, 2017 Accessed. https://www.gse.harvard.edu/news/uk/17/08/note-takinglow-tech-often-best.

[11] D. Fisher, W.G. Brozo, N. Frey, G. Ivey, Fifty Instructional Routines to Develop Content Literacy, $3^{\text {rd }}$ Edition. Pearson, 2015.

[12] R.K. Greenberg, N.A. Wilner, "Using Concept Maps to Provide an Integrative Framework for Teaching the Cost or Managerial Accounting Course", Journal of Accounting Education 33(1),16-35, 2015.

[13] E. Guterman, "Toward dynamic assessment of reading: applying metacognitive awareness guidance to reading assessment tasks", Journal of Research in Reading 25: 283-298, 2002. doi: 10.1111/1467-9817.00176.

[14] L. Hall, "Teachers and Content Area Reading: Attitudes, Beliefs and Change", Teaching and Teacher Education 21 403-414, 2005 Retrieved Teachers_and_content_area_reading_Attitu.pdf.

[15] C. Hart, "Factors associated with student persistence in an online program of study: A review of the literature", Journal of Interactive Online Learning, 11(1), 19-42, 2012. http://www.ncolr.org/jiol/issues/pdf/11.1.2.pdf.

[16] J. Holloway, "Research Link / Integrating Literacy with Content", Educational Leadership. 60(3) 87-88, 2002. Retrieved Integrating Literacy with Content - Educational Leadership (ascd.org).

[17] T.L. Jetton, P.A..Alexander, "Learning from Text: A Multidimensional and Developmental Perspective", Handbook of Reading Research, $\begin{array}{llll}\text { Volume } & \text { III, } & 2000 . & \text { Retrieved }\end{array}$ LearningfromTextsummarizedversion.pdf.

[18] D.H. Jonassen, "On the Role of Concepts in Learning and Instructional Design", Educational Technology Research and Development, 54(2), 177-196, 2006.

[19] S. Lay, "Improving Success of Undergraduate Principles of Accounting Students by Exploring New Methods", The International Journal of Learning, 15 (4), 2008.

[20] B.A. Leauby,K.A. Szabat, J.D. Maas, "Concept Mapping - an Empirical Study in Introductory Financial Accounting", Journal of Accounting Education, 19(3), 2008.

[21] S. McGuire, Teach Students How to Learn. Sterling, Virginia. Stylus, 2015.

[22] M.C. McKenna, R.D. Robinson, "Content Literacy: A Definition and Implications”, Journal of Reading, 34(3),184-186, 1990. 
[23] D. Moore, T. Bean, D. Birdyshaw, \& J. Rycik, "Adolescent Literacy: A Position Statement. Journal of Adolescent \& Adult Literacy, 43(1), 97-112, 1999. Retrieved http://www.jstor.org/stable/40017055.

[24] B. Moore, A.G. Boardman, C. Smith, \& A. Ferrell, "Enhancing Collaborative Group Processes to Promote Academic Literacy and Content Learning for Diverse Learners Through Video Reflection", Sage Open, 2019. https://doi.org/10.1177/2158244019861480.

[25] P.A. Mueller, D.M. Oppenheimer, "The pen is mightier than the keyboard: Advantages of longhand over laptop note taking", Psychological Science, 29(9), 1565-1568, 2018.

[26] J.D. Novak, A.J. Cañas, "The Theory Underlying Concept Maps and How to Construct Them” Technical Report IHMC CmapTools 2006 01 Rev 01-2008, Florida Institute for Human and Machine Cogntion, 2008.

Retrieved from http://cmap.ihmc.us/Publications/ResearchPapers/TheoryUnderl yingConceptMaps.pdf.
[27] P.D. Pearson, D.D. Johnson, Teaching reading comprehension. New York: Holt, Rinehart, \& Winston, 1978.

[28] S. Skrabut, "Small Teaching Online: Applying Learning Science in Online Classes", Quarterly Review of Distance Education 20(4) 93-97, 2019.

[29] R. Taraban., K. Rynearson, \& M.S. Kerr, "Analytic and Pragmatic Factors in College Students' Metacognitive Reading Strategies", Reading Psychology, 25(2), 67-81, 2004.

Rachel Raskin is an Assistant Professor of Accounting at the New York City College of Technology, City University of New York. She is a Certified Public Accountant with public and private accounting experience in banking and large financial institutions. 